\title{
THE CONTROL OF .PHOTOTACTIC REACTIONS IN HYALELLA BY CHEMICALS
}

\author{
HARTLEY H. T', JACKSON
}

From the Zoölogical Laboratory, University of Wisconsin

Loeb $^{1}$ in a brief preliminary paper has shown that specimens of Gammarus pulex, which are normally negatively phototactic, may be made positive if they are placed in certain chemicals of the proper degree of concentration. For example, positive phototaxis was produced when the amphipods were placed in solutions of hydrochloric, oxalic or acetic acid of about $\mathrm{m} / 500$. Loeb obtained similar results with a $2 \frac{1}{2} \mathrm{~m}$ solution of ethyl alcohol, a $\mathrm{m} / 6$ solution of ether, and a $\mathrm{m} / 25$ solution of ammonium chloride, but a $\mathrm{m} / 10$ solution of boracic acid failed to produce such an effect. My own experiments were performed on another amphipod, Hyalella knickerbockeri, in the endeavor to ascertain if Loeb's results would hold true in this species, and to test the effect of various chemicals in different concentrations. The results obtained were similar to those of Loeb, but it was found that Hyalellas were made positive by boracic acid if they were dropped into a saturated solution. Tartaric acid produces no change in their reaction.

My results with salts were quite parallel to those of Loeb; I found some ammonium salts to make them decidedly positively phototactic; some potassium salts made them weakly positive; potassium bromide and potassium iodide made them strongly positive. Potassium chloride and potassium chlorate produced no marked change in their phototactic response, nor did any of the sodium salts, or magnesium sulphate. I tried several alkalies, but here, as with the salts, there seemed to be no relation be-

${ }^{1}$ LOEB, J. The Control of Heliotropic Reactions in Fresh-water Crustacean, by Chemicals, especially $\mathrm{CO}_{2}$. University of California Publications. Physiology vol. 2, p. 1. 1904. 
tween the chemicals used and the reactions. Some potassium salts produced a change in the phototaxis of the animals, other potassium salts did not; some acids produced a change in the phototaxis, others did not. It is the same with the alkalies; ammonium hydroxide causes all the animals to become positive immediately when they are dropped into a solution of .0075 per cent, but when the animals are put into a solution of potassium hydroxide, or sodium hydroxide, or potassium carbonate of any concentration which will not kill them outright, there is no change in their phototactic response; they still remain negative. Loeb ${ }^{2}$ claims that in all probability light produces chemical changes in the eye or skin of the animals, and that these changes are responsible for the phototactic reactions. If this be true, it might seem not improbable that some definite relation would be found between the classes of chemicals employed and the reaction, but such experiments as have thus far been made tend to prove that no such relation exists.

In endeavoring to test more thoroughly the effects of chemicals upon phototaxis, experiments were conducted in the dark room, the source of light being an electric tungsten bulb of 350 candlemeters intensity. Seven chemicals were used, namely, ethyl alcohol, ammonium hydroxide, and hydrochloric, nitric, acetic, picric, and chromic acids. I first determined the lowest per cent solution of each of these chemicals which would cause a reversal in the phototactic reaction of the Hyalellas; in other words, the least per cent solution which would make them positive when they were dropped directly into it. I found that ethyl alcohol of .074 per cent, ammonium hydroxide of .0075 per cent, hydrochloric acid of .0067 per cent, nitric acid of .0053 per cent, acetic acid of .01 per cent, picric acid of 0053 per cent, and chromic acid of .0046 per cent would produce this result. In each of these cases, all or nearly all the animals would be in the positive end of the dish making frantic efforts to get nearer the source of light. My next experiment was to place several of the animals in an oblong glass dish, four inches long and one and one-half inches

${ }^{2}$ Loeb, J. Comparative Physiology of the Brain and Comparative Psychology. New York, 1900, and l.c. 
wide, containing twenty-five cubic centimeters of distilled water. Very slowly and gradually the concentration of the solution was increased by adding constant small amounts of a given chemical at intervals of five to fifteen minutes. A careful record was kept of the number of animals positive and the number negative at certain concentrations throughout the experiments. In every case the light was moved and the reaction of the animals tested from each end of the dish; that is, when the animals had oriented themselves in one end of the dish, the light was then transposed to that end and the reaction tested again. The results were surprising; in each case the amphipods remained decidedly negatively phototactic, even though the concentration was carried far beyond the point at which they became positive when dropped directly into the solution. The concentration in each case was increased to the point where the majority of the animals died; nevertheless they were negative, and decidedly so, throughout the experiment until death occurred. Thus, when the concentration is gradually increased, the Hyalellas were negative in .64 per cent solution of ethyl alcohol, .05 per cent solution of ammonium hydroxide, .022 per cent hydrochloric acid, .05 per cent nitric acid, .43 per cent acetic acid, .029 per cent picric acid, and 0.22 per cent chromic acid. The results will appear more evident by a study of the accompanying table. In this table the first column of figures indicates the per cent solution; following each of these figures, to the right, is indicated the number of animals which were positive and the number negative at each reading of a given chemical at a concentration given in the first column. The line drawn across each column indicates the point at which the animals were positively phototactic when dropped directly into the solution. Where the sum of the positive and negative specimens is not equal to the sum of the positive and negative used at the beginning of the experiment, it indicates that a number of animals died from the effect of the chemical.

It is evident that it is not chemical change in the tissues which caused the reversal of reaction, for, if it were, it would be impossible to increase the concentration and still have the animals 
TABLE OF PHOTOTACTIC REACTION IN HYALELLA.

\begin{tabular}{|c|c|c|c|c|c|c|c|}
\hline \multirow{2}{*}{$\begin{array}{l}\text { PER CENT } \\
\text { SOLUTION } \\
\text { USED }\end{array}$} & $\begin{array}{l}\text { NITRIC } \\
\text { ACID }\end{array}$ & $\begin{array}{l}\text { ACETIC } \\
\text { ACID }\end{array}$ & $\begin{array}{l}\text { PICRIC } \\
\text { ACID }\end{array}$ & $\underset{\text { ACID }}{\text { CHROMIC }}$ & $\begin{array}{l}\text { HYDRO- } \\
\text { CHLORIC } \\
\text { ACID }\end{array}$ & $\begin{array}{c}\text { AMMONI- } \\
\text { UM HY- } \\
\text { DROXIDE }\end{array}$ & ALCOHOL \\
\hline & $\begin{array}{l}\text { No. } \\
+-\end{array}$ & $\begin{array}{l}\text { No. } \\
+-\end{array}$ & $\begin{array}{l}\text { No. } \\
+-\end{array}$ & No. & $\begin{array}{l}\text { No. } \\
+-\end{array}$ & $\begin{array}{l}\text { No. } \\
+-\end{array}$ & $\begin{array}{l}\text { No. } \\
+-\end{array}$ \\
\hline .0000 & 021 & $0 \quad 17$ & 020 & 018 & 120 & 020 & 020 \\
\hline .0008 & 021 & 017 & 020 & 018 & 021 & 020 & 119 \\
\hline .0016 & 021 & 116 & 020 & 018 & 021 & 020 & 020 \\
\hline .0023 & 021 & 017 & 020 & 117 & 021 & 020 & 020 \\
\hline .0031 & 021 & 017 & 020 & 018 & 021 & 020 & 020 \\
\hline .0038 & 021 & 017 & 020 & 018 & 021 & 020 & 020 \\
\hline .0046 & 021 & 017 & 020 & 117 & 021 & 020 & 020 \\
\hline 0053 & 021 & 017 & 020 & 215 & 021 & 020 & 020 \\
\hline .0060 & 021 & 017 & 119 & 113 & 021 & 020 & 020 \\
\hline .0067 & 021 & 017 & 416 & 014 & 021 & 020 & 020 \\
\hline .0075 & 021 & 017 & 216 & $0 \quad 9$ & 021 & 020 & 020 \\
\hline .0100 & 021 & $\overline{017}$ & 114 & $0 \quad 9$ & 021 & 119 & 020 \\
\hline .015 & 021 & 017 & 112 & 07 & 014 & 019 & () 20 \\
\hline .022 & 021 & 017 & 111 & 04 & $\begin{array}{ll}0 & 3\end{array}$ & 115 & 020 \\
\hline .029 & 021 & 116 & 28 & & & 112 & 020 \\
\hline .036 & $0 \quad 19$ & 017 & & & & $\begin{array}{ll}0 & 12\end{array}$ & 020 \\
\hline .043 & 013 & 017 & & & & 07 & 020 \\
\hline .050 & 04 & 116 & & & & 05 & 020 \\
\hline .060 & & 017 & & & & & 020 \\
\hline .067 & & 017 & & & & & 020 \\
\hline .074 & & 017 & & & & & 119 \\
\hline .100 & & 017 & & & & & 119 \\
\hline .150 & & 116 & & & & & 020 \\
\hline .220 & & 017 & & & & & 020 \\
\hline .290 & & 017 & & & & & 118 \\
\hline .360 & & 014 & & & & & 019 \\
\hline .430 & & 06 & & & & & 018 \\
\hline .500 & & & & & & & 018 \\
\hline .570 & & & & & & & 018 \\
\hline .640 & & & & & & & 0 18 \\
\hline
\end{tabular}


remain negative; even though the increase be gradual, the chemical change in the eye or skin of the animal would take place as readily when the necessary concentration was reached as when the animal was dropped directly into the concentrated chemical. Moreover, the duration of immerison in the chemical is greater when the concentration is gradually increased; this would tend to produce a more complete chemical change in the animal than when it is dropped momentarily into the chemical. It is probable, therefore, that these various changes of reaction are due, not to chemical changes in the eyes or skin of the animal, but to a sudden stimulation or shock to the nervous system.

I wish here to express my acknowledgments and thanks to Dr. S. J. Holmes for his kindly criticisms and ajd in preparing this paper. 